REVIEW

\title{
Cachexia in malaria and heart failure: therapeutic considerations in clinical practice
}

\author{
M E Onwuamaegbu, M Henein, A J Coats
}

Postgrad Med J 2004;80:642-649. doi: 10.1136/pgmi.2004.020891

Cachexia is an independent prognostic marker of survival in many chronic diseases including heart failure and malaria. Morbidity and mortality from malaria is high in most of the third world where it presents a very challenging public health problem. Malaria may present in the UK as fever in the returning traveller or as fever in overseas visitors. How and why cachexia develops in malaria in a manner similar to the cachexia of chronic heart failure and the treatment strategies that would alter outcomes in both diseases are discussed in this review.

See end of article for authors' affiliations

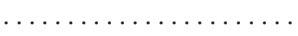

Correspondence to: Dr Meto E Onwuamaegbu, Department of Clinical Cardiology, Royal Brompton Hospital, Sydney Street, London SW3 6NP, UK; drmeto@ doctors.net.uk

Submitted

29 February 2004

Accepted 23 April 2004
C achexia is an important feature of many chronic disorders. It occurs in infectious ducerculosis, and in many other chronic illnesses including heart failure, liver cirrhosis, chronic obstructive pulmonary disease, cystic fibrosis, chronic renal failure, and malignancy. It is important to specifically compare cachexia in malaria and heart failure because data from research in recent years suggests that the aetiology may be similar. This may have significant clinical considerations for the specialties that are involved in the management of patients with these conditions. This comparison may explore common themes that will enable us to selectively target cachexia irrespective of its cause and modify disease prognosis. This paper aims to review the evidence for cachexia in malaria and heart failure and to highlight common denominators in aetiology, clinical manifestation, or treatment.

\section{METHODS}

Papers reviewed were identified by searching Medline (1966 to January 2004), the Cochrane Database of Systematic Reviews, EMBASE, DARE, ACP Journal Club, Excerpta Medica, the Cochrane Controlled Trials Registry, and by reviewing the bibliography of relevant articles.

MALARIA

The protozoa that cause malaria are:

- Plasmodium falciparum.

- Plasmodium malariae.

- Plasmodium vivax.

- Plasmodium ovale.

Ninety five percent of deaths occurring in malaria worldwide are due to Plasmodium falciparum. ${ }^{1}$ Malaria is transmitted by the bite of its insect vector, the anopheles mosquito, which also acts as a reservoir of infection. It may rarely be transmitted by blood transfusion, injection, or transplacentally. The clinical picture of $P$ falciparum malaria typically includes fever, malaise, joint pains, anorexia, headache, nausea and vomiting, and cough and may progress to delirium, seizures, renal failure, coma, and death. This is because falciparum malaria is a complex disease that causes multiorgan dysfunction. ${ }^{2}$ This is thought to occur through the excessive stimulation of inflammatory and immunological pathways mediated by proinflammatory cytokines.

The hallmark of malaria is haemolysis, which occurs when the red blood cells rupture to release schizonts. Rupture of schizonts liberates antigenic substances and toxins, which can cause widespread organ damage and failure. In falciparum malaria, red blood cells containing schizonts adhere to the lining of capillaries in brain, kidney, liver, lungs, and the gut. These vessels become congested and anoxia may develop within the organs. Repeated malaria attacks can result in long standing devitalisation that will ultimately lead to cachexia.

The interaction between malaria and cachexia is complex. Some workers have attempted to relate this interaction to socioeconomic factors and malnutrition, while others emphasise the importance of co-morbidity, and yet others stress the role of anaemia. The protective effect of intestinal helminths and chronicity is proposed to confound the malaria-cachexia interaction. Factors due to the frequency of parasite inoculation are also important. Malaria is a source of great morbidity and mortality. Immunity accrues slowly in survivors, over a period of years, and the immune response is not capable of protecting from reinfection. The most vulnerable are the individuals who lack adequate immunity: young children, pregnant women, and people with no previous exposure. ${ }^{3}$

\section{Chronic malaria}

There is no agreed definition for chronic malaria. In this review, we have used the term "chronic malaria" to mean three or more acute attacks of malaria within one year in an individual with low levels of parasitaemia but not symptoms of malaria between attacks. This is different from recurrent malaria in which there is complete elimination of parasitaemia between attacks.

Abbreviations: $\mathrm{CHF}$, chronic heart failure; GPI, glycosylphosphatidylinositol; HMG CoA, 3-hydroxy-3methylglutaryl coenzyme $\mathrm{A}$; IL, interleukin; $\mathrm{MHCl}$, myosin heavy chain isoform; TNF, tumour necrosis factor; WHO, World Health Organisation 
Thus chronic malaria is a frequent feature of the indigenous population in endemic areas. It may well represent an adaptation by the host to survive repeated parasitic invasion or evolution by the parasite to exist successfully within the host.

\section{Public health challenge}

About 100 million people worldwide are subject to malaria infection annually, of whom $1 \%$ will die during the acute illness. About $90 \%$ of the worldwide malaria burden is borne by sub-Saharan Africa, and lately, the disease has reappeared in previously malaria-free areas as a result of epidemics, the decline in public health systems, and drug resistance. ${ }^{4}$ The World Health Organisation (WHO) report of 1997 states that about $40 \%$ of the world's population is at risk of malaria. ${ }^{5}$ This percentage at risk may increase if the disease continues to spread at the present rate. Specifically, about 25-30 million people from non-tropical countries will visit areas in which malaria is endemic yearly. Out of this number, about 10000 to 30000 will become infected. ${ }^{6}$

\section{Molecular basis of the pathogenesis of falciparum malaria}

It was the Italian physician Camillo Golgi who first hypothesised in 1886 that the cause of the febrile paroxysm in malaria was the release of a toxin of parasite origin. ${ }^{7}$ Maegraith in 1948 posited that the various pathological processes in malaria were the results of the induction of endogenous mediators of host origin. ${ }^{8}$ There is now evidence to suggest that host cells, acting under the influence of the parasite $P$ falciparum, trigger the release of pro-inflammatory cytokines, which then provokes its onset. There are studies showing a close correlation between disease severity and circulating levels of tumour necrosis factor (TNF) in both children and adults. ${ }^{9}$ These cytokines can generate the inducible form of nitric oxide synthase and thus produce a continuous large supply of nitric oxide in tissues and cause cerebral symptoms, immune suppression, and weight loss. ${ }^{11}$

\section{CD4+ T-cells in malaria}

CD4+ T-cells are thought to have a role in immunity to the blood stages of malaria, and cytokines associated with monocyte and T-cell activation have been implicated in the disease. $^{12}$ Similar cytokines are known to occur in the pathogenesis of cachexia in heart failure.

\section{Glycosylphosphatidylinositol (GPI)}

GPI produced by $P$ falciparum is a parasite toxin inducing the production of TNF and interleukin (IL)-1 by host macrophages. This exerts its effect by the activation of a two component signalling pathway within the host cells. ${ }^{13}$ GPI causes TNF-mediated weight loss in mice. ${ }^{14}$

\section{Overlap of symptomatology: algid malaria}

Algid malaria is a shock-like syndrome. Most patients with severe falciparum malaria exhibit a raised cardiac index $\left(>5 \mathrm{l} / \mathrm{min} / \mathrm{m}^{2}\right)$, which can be traced to pyrogen-mediated vasodilatation with low systemic vascular resistance and low or normal pulmonary arterial wedge pressures. The WHO report on falciparum malaria in 2000 states that the clinical picture produced in algid malaria is similar to Gram negative septicaemia. ${ }^{5}$ Endotoxaemia also occurs in patients with falciparum malaria. ${ }^{15}$ An agonal fall in cardiac index secondary to metabolic acidosis, hypoxaemia, and septicaemia may occur. This is similar to what is observed in the final stages of heart failure from non-cardiac causes, especially that associated with end stage renal disease and sepsis. Malaria may thus be viewed as a collection of overlapping syndromes acting through different organ systems with several mechanisms. ${ }^{16}$

\section{Immunity to falciparum malaria}

Plasmodium falciparum is one of the most virulent human pathogens. The factors that determine its virulence are poorly defined, although the adhesion of infected red blood cells to the vascular endothelium has been associated with some of the syndromes of severe disease. Immune responses cannot prevent repeated attacks of malaria. Specific immunity has been attributed either to the presence of cytotoxic lymphocytes that act against the parasite's liver stage of infection or to antibodies that react against blood stage antigens. Antigenic diversity, clonal antigenic variation and T-cell antagonism may contribute to the parasite's evasion of the protective and parasiticidal host responses. It is proposed that an understanding of immunity in the setting of malaria may be the link to understanding how cachexia develops in chronic heart failure (CHF) with a known similar cytokine profile.

\section{Evidence for cachexia in malaria}

The studies that provide the evidence for the occurrence of cachexia in chronic malaria are summarised in table 1. Various workers have studied the relationship between malarial immunity and nutritional status. In Tanzania, no correlation was found between malaria antibody titres and indices of malnutrition. ${ }^{17}$ In Kenya, a variant surface antigen specific IgG in chronic pregnancy associated malaria was found to protect against low birth weight. ${ }^{18}$ In Colombia, mean antibody titres to $P$ falciparum were lower in malnourished children than in well nourished ones. $P$ vivax antibody titres were higher in malnourished children. ${ }^{19}$ There is evidence from observational cohorts that malnutrition decreases the susceptibility to malaria and that this may be due to an interaction with host immunity. ${ }^{20}$ There is also evidence that malnutrition worsens the prognosis in malaria. ${ }^{21}$ The level at which malnutrition ceases to become protective and becomes an adverse prognosticator is not clear. The host immunity described is related to "stunting" and "wasting" rather than malnutrition. Stunting has been shown to be protective in malaria. Thus, it has been proposed that the improved ability of malnourished children to produce certain cytokines in response to stimulation by specific malarial antigens may be the key. ${ }^{22}$ Tanner et al reported that malaria was the main contributory factor to growth retardation in children in a hyperendemic rural community of Tanzania. ${ }^{23}$ Mbago et al determined that malaria was a significant predictor of weight for height measurements in underweight children living in holoendemic areas of urban Tanzania. ${ }^{24}$ We have not found any studies that addressed directly the issue of the response of cachexia to treatment interventions in malaria and how this might affect prognosis. However, a small study by Van Den Broeck et al in 1993 found an association between nutritional status and mortality risk and extreme malnutrition in holoendemic areas of Zaire. ${ }^{25}$

Similarly, there are no large studies involving long term endpoints on the effect of long term suppression of parasitaemia in chronic malaria in endemic areas and the relationship to cachexia and prognosis. Because manipulation of cachexia may modify chronic disease, it is important to design and conduct large intervention studies in chronic malaria to see whether manipulation of either endpoint will affect prognosis or other outcome measures when both endpoints occur together.

\section{HEART FAILURE}

"Heart failure is a fascinating cluster of syndromes, full of paradoxes, defies simple definition yet is common and deadly". ${ }^{26}$ The 2001 guidelines issued by the Task Force for the Diagnosis and Treatment of Chronic Heart Failure of the 


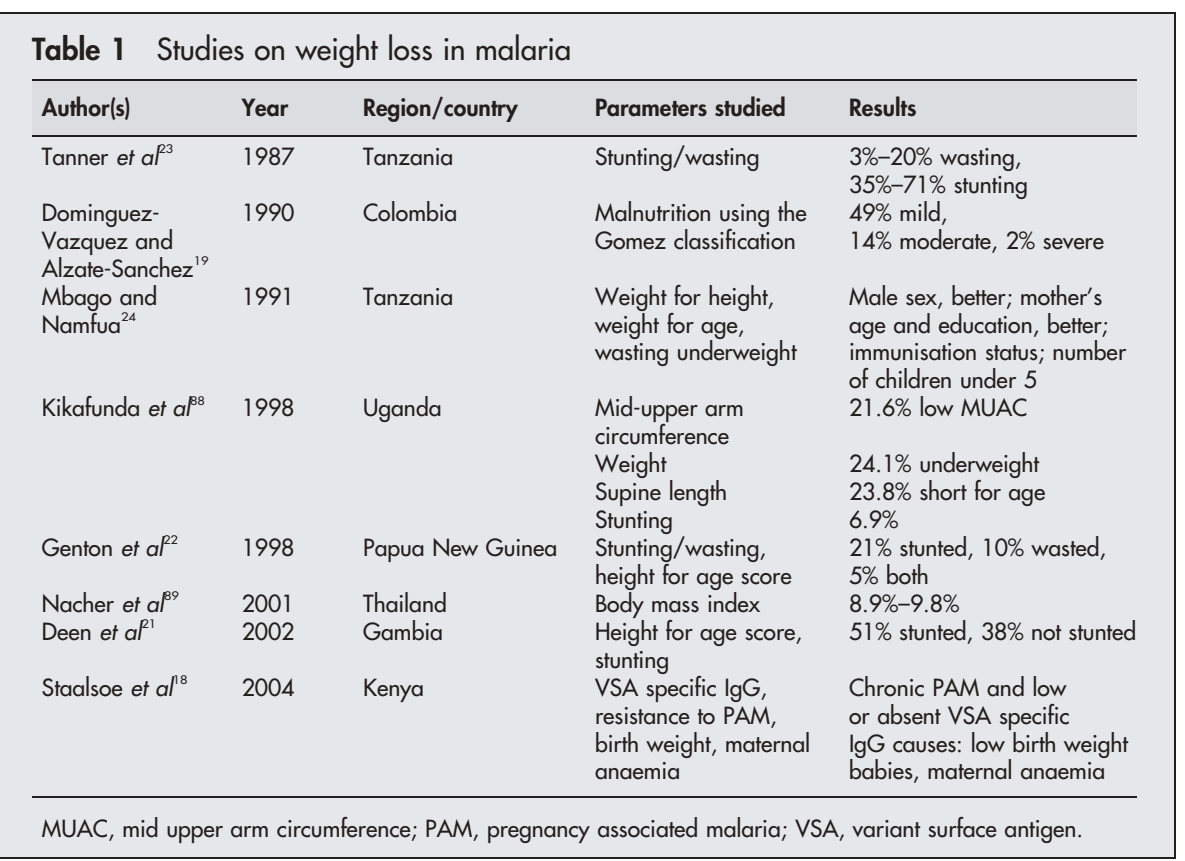

European Society of Cardiology states that heart failure is a syndrome containing certain key features typically breathlessness or fatigue, either at rest or during exertion, or ankle swelling plus an objective evidence of cardiac dysfunction at rest. That a clinical response to treatment directed at heart failure should demonstrate some improvement in symptoms and/or signs. ${ }^{27}$

\section{Cachexia in $\mathrm{CHF}$}

Cachexia is an adverse prognosticator in heart failure. ${ }^{28}$ There is considerable disagreement in the question of the percentage of heart failure patients who develop cachexia and how this should be defined and measured. Carr et al reported that up to $50 \%$ of patients with CHF suffered from some form of malnutrition. ${ }^{29}$ Anker and Coats published that up to $15 \%$ of patients attending their CHF clinic developed cachexia during the clinical course of CHF. ${ }^{30}$ Roubenoff et al observed that loss of more than $40 \%$ of lean body tissue would cause death. ${ }^{31}$ Several studies show that CHF is characterised by persistent immune activation in vivo. This is reflected in the increased levels of inflammatory cytokines TNF, IL- $1 \beta$, and IL-6; and chemokines monocyte chemoattractant protein-1 and IL-8 within the blood and the enhanced expression of various inflammatory mediators within the failing myocardium.

\section{Competing theories}

There are several theories for the causes of cachexia in CHF. Figure 1 shows the factors that are known to affect the development of cachexia in chronic diseases like CHF and the relationship between these factors. We point out, however, that it would be difficult to propose a specific hypothesis regarding molecular mechanisms of cachexia as the different mechanisms and pathways proposed have not been fully defined.

\section{Physical inactivity and muscle atrophy}

Widespread abnormalities of skeletal muscle bulk, function, and metabolism is a recognised consequence of CHF. Around 400 BC, a syndrome of "heart failure" in which the "shoulders, clavicles, chest and thighs melt away" was described by a scholar from the school of Hippocrates. ${ }^{32}$ William Withering in 1795 wrote of a patient with heart failure as someone "whose body was greatly emaciated". ${ }^{33}$ There is recent evidence to support this. ${ }^{34}{ }^{35}$ Physical inactivity and deconditioning may play a part in the muscle atrophy seen in many chronic disease states, although in CHF this atrophy is significantly different from that observed in physical inactivity.

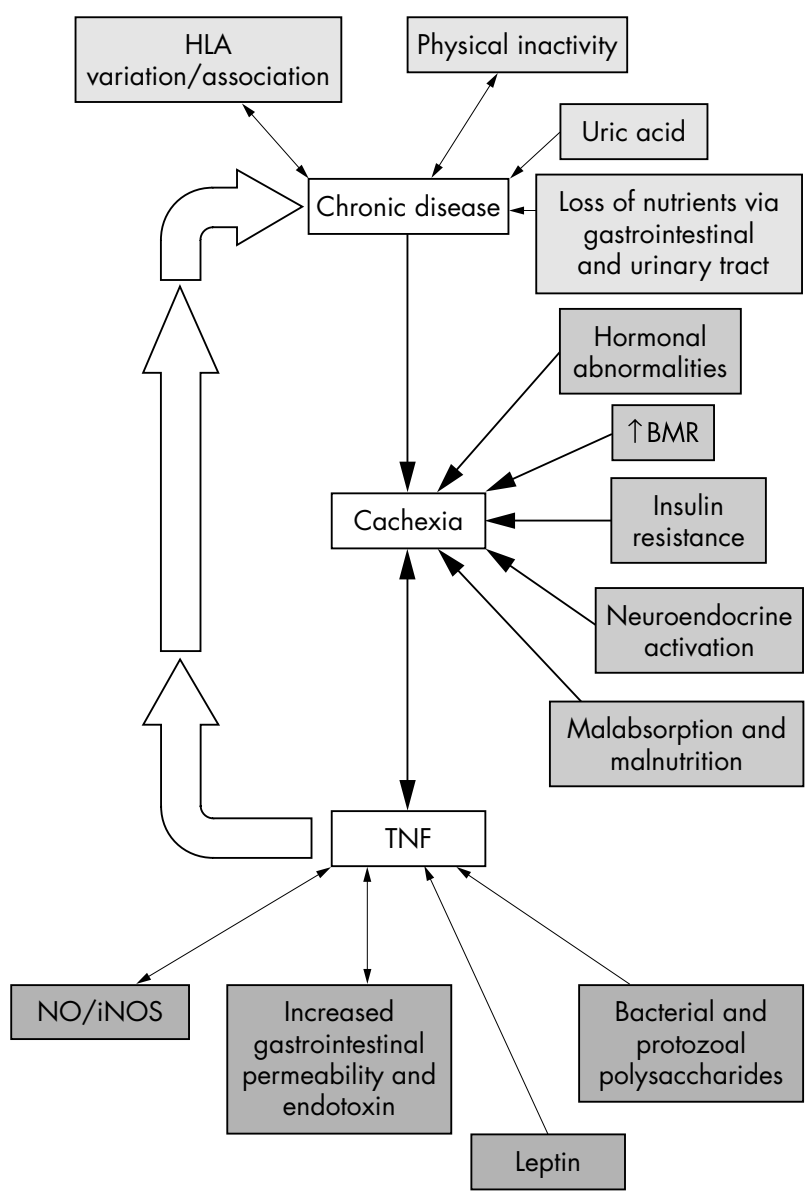

Figure 1 Interplay between chronic disorders and cachexia (BMR, basal metabolic rate; NO/iNOS, nitric oxide/inducible form of nitric oxide synthetase; TNF, tumour necrosis factor). 


\section{Muscle hypothesis}

Coats et al postulated that haemodynamic alterations trigger the development of complex peripheral alterations which contribute to sympathetic excitation during exercise and symptom generation and degeneration. ${ }^{36}{ }^{37}$ Regular exercise increases skeletal muscle bulk and improves survival in CHF.

\section{Chronic low frequency electrical stimulation}

A small clinical trial by Nuhr et al reported that four hours a day of chronic low frequency stimulation for 10 weeks improved exercise performance and significantly increased peak oxygen uptake. ${ }^{38}$ These changes were associated with changes in the profiles of the enzymes citrate synthase and glyceraldehydephosphate dehydrogenase, and the myosin heavy chain isoforms (MHCIs) were shifted in the slow direction. The increases in the MHCI slow isoform was at the expense of the MHCIId/x fast isoform suggesting an increase in lean muscle mass and improvement in deconditioning due to $\mathrm{CHF}^{37}$

\section{Neurohormonal hypothesis}

Merrill et al reported an increased concentration of renin in the blood of patients with CHF. ${ }^{39}$ Subsequently the mechanism for salt and water retention in CHF was described. ${ }^{40}$ The concept that neuroendocrine activation is central to the pathogenesis and prognosis of heart failure is well established. ${ }^{41}{ }^{42}$ Packer used the neurohormonal hypothesis to postulate that CHF progresses because activated endogenous neurohormonal systems are deleterious to the heart and cardiovascular system. ${ }^{43}$ Thus catecholamines are now accepted to be raised in cachexia because of heart failure. ${ }^{44}$

\section{Cytokines in CHF}

Levine et al observed that patients with severe CHF had raised circulating levels of TNF. ${ }^{45}$ This was followed by reports of increased concentrations of TNF in patients with cardiac cachexia. The clinical significance of these observations is that TNF elevation in CHF is associated with marked activation of the renin-angiotensin system, cachexia, advanced disease, and an adverse prognosis. ${ }^{46}$ It has also been observed that the TNF receptor family $\left(\mathrm{F}_{\mathrm{as}}\right)$ transduces the apoptotic signal into cells. And there are reports of the occurrence of apoptosis with abnormal consequences in the human heart. ${ }^{47}$ TNF is now thought to play a significant part in left ventricular remodelling.

\section{Insulin resistance}

Insulin resistance and the development of the metabolic syndrome have been implicated as a contributing cause of cachexia in $\mathrm{CHF}^{48}$ In infectious diseases, hyperinsulinaemia and insulin resistance are commonly associated with hypoglycaemia. In malaria, insulin resistance may also occur in association with hypoglycaemia. ${ }^{49}$ It may be due to parasitaemia or treatment with quinine.

\section{Dehydroepiandrosterone/cortisol ratio, growth hormone, and basal metabolic rate}

The role of hormonal changes, dehydroepiandrosterone/ cortisol ratio, growth hormone, and insulin-like growth factor as underlying the severe metabolic and endocrine abnormalities in these diseases was described by Anker et al. ${ }^{39}$ An increase in basal metabolic rate is thought to be central to this.

\section{Leptin}

Leptin may also play a part in cachexia. Like cytokines, leptin serves as a peripheral messenger to convey signals to the brain. Expression of leptin is stimulated by glucocorticoids, endotoxins, and cytokines and its actions include inhibition of the hypothalmo-pituitary-adrenal axis. Indeed leptin exerts a direct, dose dependent inhibition of stimulated cortisol secretion by normal human and rat adrenal cells in vitro. ${ }^{50}$ Adipocytes are implicated in the cachexia seen in malaria. ${ }^{51}$ The evidence is not clear..$^{52}$

\section{Malnutrition/malabsorption}

Malnutrition and malabsorption are well known causes of cachexia in chronic diseases. Losses of nutrients through the gastrointestinal and urinary tracts are other mechanisms proposed as possible causes. In CHF increased right atrial pressure and tricuspid regurgitation is associated with whole body protein turnover and cachexia. ${ }^{53} 54$ What is not so clear is whether this is a cause or effect.

\section{COMPARISON BETWEEN CACHEXIA IN CHF AND CACHEXIA IN MALARIA}

The body of evidence discussed above shows that many immunological, physiological, and clinical features are

Table 2 Comparison between cachexia in CHF and cachexia in malaria

\begin{tabular}{|c|c|}
\hline Chronic heart failure & Malaria \\
\hline $\begin{array}{l}\text { HLA association not known. } \\
\text { Genotypes not known to } \\
\text { ameliorate disease severity }\end{array}$ & $\begin{array}{l}\text { Strong HLA association with disease } \\
\text { severity. Also AS genotype associated } \\
\text { with protection from disease }\end{array}$ \\
\hline Associated with malnutrition & Associated with malnutrition \\
\hline $\begin{array}{l}\text { Skinfold thickness associated } \\
\text { with prognosis }\end{array}$ & $\begin{array}{l}\text { Decrease in skinfold thickness is an } \\
\text { adverse prognosticator especially in } \\
\text { severe disease }\end{array}$ \\
\hline $\begin{array}{l}\text { Respiratory distress and } \\
\text { pulmonary oedema } \\
\text { frequently present }\end{array}$ & $\begin{array}{l}\text { Respiratory distress and pulmonary } \\
\text { oedema when present is an ominous } \\
\text { sign }\end{array}$ \\
\hline $\begin{array}{l}\text { Nitric oxide implicated in } \\
\text { the pathogenesis }\end{array}$ & $\begin{array}{l}\text { Nitric oxide has a central and } \\
\text { deleterious role in cerebral malaria }\end{array}$ \\
\hline $\begin{array}{l}\text { Prostaglandins } D_{2}, E_{2} \\
\text { production increased }\end{array}$ & $\begin{array}{l}\text { Prostaglandins } D_{2}, E_{2} \text { production } \\
\text { increased }\end{array}$ \\
\hline $\begin{array}{l}\text { Multiorgan failure a feature } \\
\text { of the terminal stages of CHF }\end{array}$ & $\begin{array}{l}\text { Multiorgan failure especially liver, } \\
\text { kidney and bone marrow failure } \\
\text { present }\end{array}$ \\
\hline $\begin{array}{l}\text { High blood levels of TNF } \\
\text { present }\end{array}$ & $\begin{array}{l}\text { High blood levels of TNF present. } \\
\text { Inhibition of TNF levels beneficial }\end{array}$ \\
\hline $\begin{array}{l}\text { Increased production of } \\
\text { IL-6, IL-1 }\end{array}$ & $\begin{array}{l}\text { Increased production of IL-6, IL-1, in } \\
\text { cachexia associated with moderate } \\
\text { disease } \\
\text { Decreased production of anti- } \\
\text { inflammatory cytokine IL-10, IL-12 in } \\
\text { severe malaria }\end{array}$ \\
\hline $\begin{array}{l}\text { High serum uric acid is a } \\
\text { marker of systemic } \\
\text { inflammation }\end{array}$ & $\begin{array}{l}\text { High serum uric acid associated with } \\
\text { more severe disease }\end{array}$ \\
\hline $\begin{array}{l}\text { High blood levels of } \\
\text { cholesterol beneficial }\end{array}$ & $\begin{array}{l}\text { High blood levels of cholesterol } \\
\text { associated with fewer and less severe } \\
\text { malarial attacks }\end{array}$ \\
\hline $\begin{array}{l}\text { Increased gastrointestinal } \\
\text { permeability associated } \\
\text { with endotoxin levels }\end{array}$ & $\begin{array}{l}\text { Increased gastrointestinal permeability } \\
\text { associated with severe } P \text { falciparum } \\
\text { infection }\end{array}$ \\
\hline $\begin{array}{l}\text { Bacterial lipopolysaccharide } \\
\text { triggers release of } \\
\text { proinflammatory cytokines }\end{array}$ & $\begin{array}{l}\text { Plasmodial lipopolysaccharide } \\
\text { triggers release of proinflammatory } \\
\text { cytokines. GPI also known to induce } \\
\text { TNF and IL-1 production by } \\
\text { macrophages and TNF-mediated } \\
\text { cachexia }\end{array}$ \\
\hline $\begin{array}{l}\text { Hypoinsulinaemia associated } \\
\text { with insulin resistance and the } \\
\text { onset of the metabolic } \\
\text { syndrome }\end{array}$ & $\begin{array}{l}\text { Hyperinsulinaemia associated with } \\
\text { hypoglycaemia and anti-malarial } \\
\text { treatment. Insulin resistance associated } \\
\text { with chronicity }\end{array}$ \\
\hline $\begin{array}{l}\text { Growth hormone and insulin- } \\
\text { like growth factor implicated } \\
\text { in pathogenesis of disease }\end{array}$ & $\begin{array}{l}\text { Growth hormone and somatostatin } \\
\text { analogues modulate severity of } \\
\text { disease }\end{array}$ \\
\hline
\end{tabular}


common to those with chronic malaria and CHF. Table 2 provides a list of the key features. How useful is this background knowledge? We recognise some of these features may not apply in routine clinical settings, because they are still experimental. We have nonetheless provided them because there are on-going efforts by researchers to make some of them the routine therapeutic considerations of the future.

\section{CYTOKINES IN MALARIA}

Malaria infected individuals produce large amounts of proinflammatory cytokines. This cytokine response is responsible for the high levels of fever that occur within a few days of the inoculation of non-immune individuals with Plasmodium spp..$^{55}$ The idea that cachexia in malaria is mediated by TNF was first mooted by Hotez et al. ${ }^{56}$ Animal models have shown that weight loss in malaria is influenced by TNF. Blocking TNF in mice that received parasite specific T-cells prolongs survival. ${ }^{57}$ In human studies the production of proinflammatory cytokines like IL-1, IL-6, and TNF have been shown to mediate the clinical progress of fever, anorexia, and weight loss. ${ }^{58}$ TNF as noted in CHF above, acts by inducing the synthesis of IL-6, and by the induction of nitric oxide synthesis. Details of various studies of cytokines in malaria are summarised in table 3. TNF is down-regulated by IL-10 in children living in malaria holoendemic areas of Kenya and appears to inhibit the production of erythropoietin. Raised serum concentrations of TNF have been reported in malaria, and high concentrations correlate with increasing disease severity. IL-10 is also increased in malaria, and has been shown to down-regulate TNF. Severe anaemia has been associated with severe malaria in Ghanaian children with defective IL-10 production. Previously, it was shown that IL-10 gene knockout mice develop more severe disease and experienced higher mortality rates than normal mice, prompting the suggestion that children with $P$ falciparum infection who produce balanced levels of IL- 10 to regulate excessive TNF are better able to control severe anaemia, and the observation that severe anaemia may be a further consequence of the deranged immunology seen in malaria. ${ }^{59}$ It has thus been proposed that the balance between IL-10 and TNF may modulate the severity of anaemia in malaria in children. ${ }^{60}$

\section{CYTOKINES IN CHF}

TNF, IL-1 $\beta$, and IL-6 are known to have important pathogenic roles in $\mathrm{CHF}$, and may contribute to cachexia associated with $\mathrm{CHF}^{66}{ }^{67}$

\section{COMPARISON OF PLASMA TNF IN CHF AND MALARIA}

Figure 2 was derived from the data published by Kurtzhals et al and Cicoira et al. ${ }^{68}{ }^{69}$ It shows plasma levels of TNF in a normal population, CHF patients, and malaria patients. They provide no direct comparison and should be interpreted with caution. The methodologies employed in assaying and analysing the samples are not the same, and the Kurtzhals group did not screen for chronic malaria. However, the trend is that TNF levels are highly raised in the acute event like malaria and increased to a lesser amount in CHF. Whether an acute event with highly raised TNF levels occurs before the onset of CHF is not yet known. Clearly more studies are needed to confirm absolute TNF and endotoxin levels in all stages of both diseases before postulating a common denominator.

\section{GENETIC REGULATION OF TNF EXPRESSION}

TNF- $\alpha$ related cachexia in malaria might be influenced by the genetic make-up of individuals and populations. TNF- $\alpha$ has two subtypes (TNF- $\alpha \mathrm{l} / \mathrm{TNF}-\alpha 2$ ) and severe malaria is found significantly more frequently in heterozygotes. ${ }^{70}$ Rates of TNF- $\alpha$ subtypes vary between populations and may influence susceptibility to severe malaria and cachexia. ${ }^{71}$

\section{THERAPEUTIC AND PROGNOSTIC IMPLICATIONS}

Cachexia complicating any chronic disease state is associated with an increased risk of death during the course of that disease. Anker et al have suggested that the loss of more than

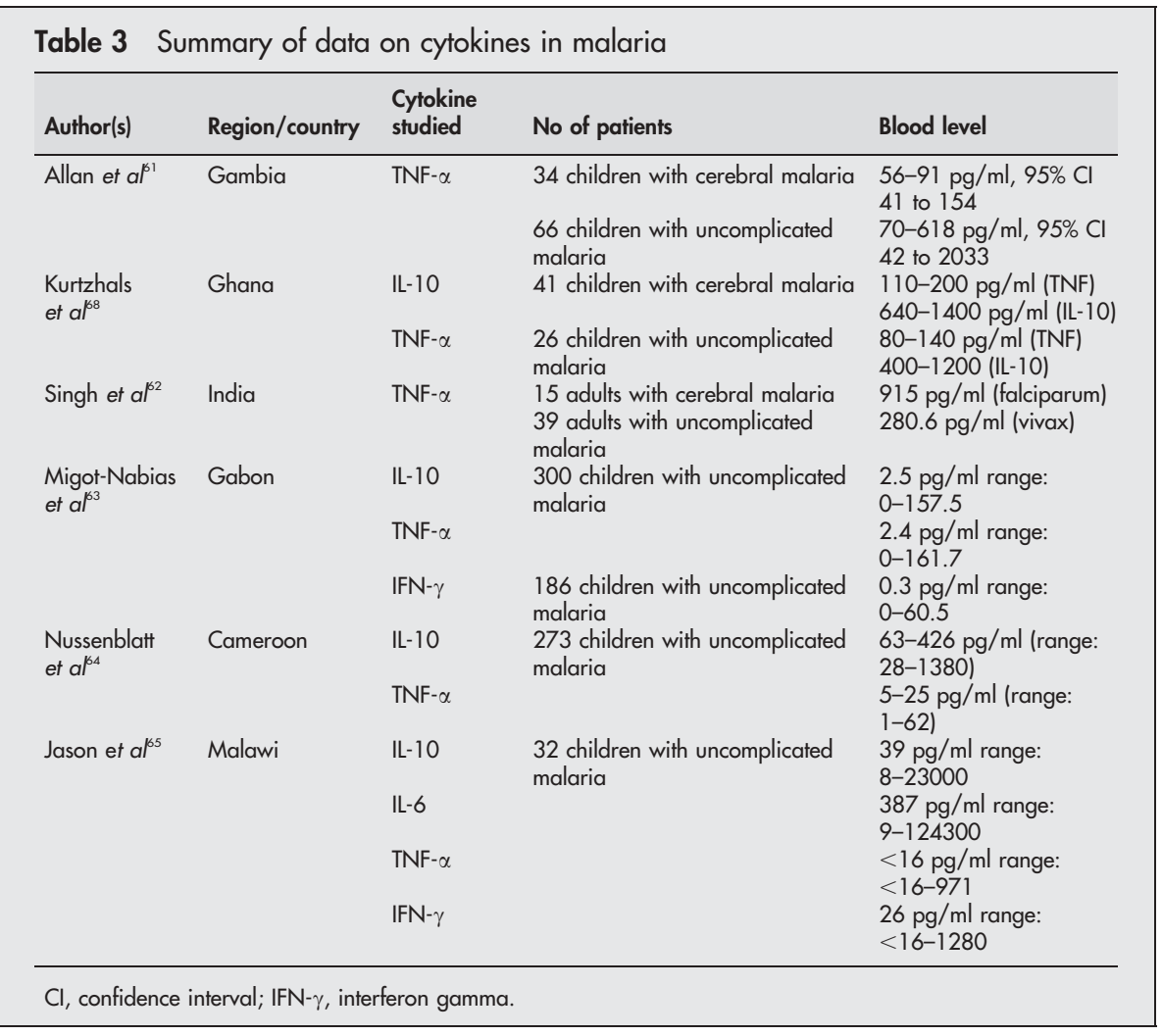



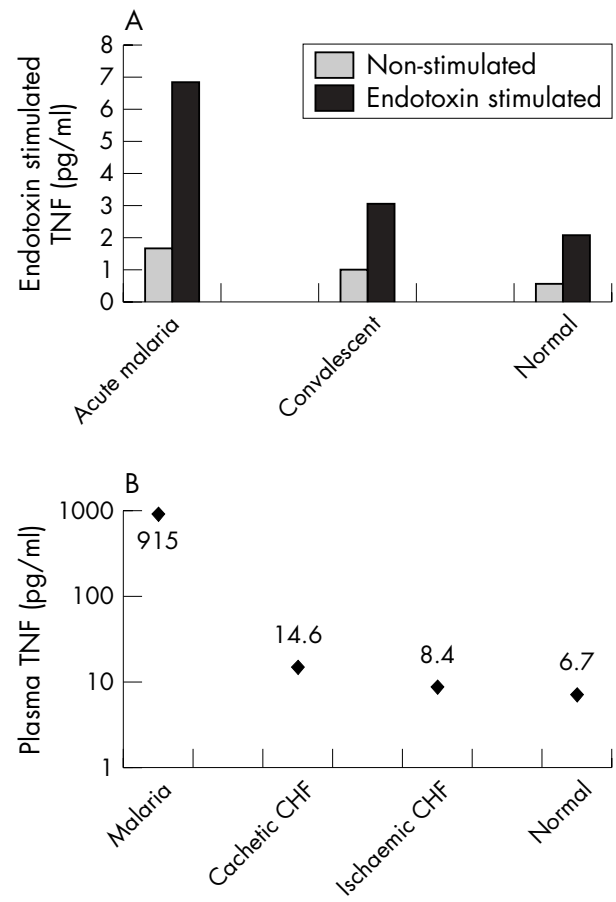

Figure 2 (A) In vitro endotoxin stimulated TNF production in falciparum malaria; (B) comparison of plasma TNF levels in malaria and CHF.

$6 \%$ of the pre-morbid body weight or the presence of a body mass index $<15$ in an adult being treated for a chronic disease should prompt heightened therapeutic consideration. ${ }^{72}$ This may include:

- Nutritional support.

- Exercise training. ${ }^{73}$

- Periodic weighing or a carefully documented weight history.

- Modification of lipid profile.

- Anticytokine therapy.

- Intravenous immunoglobulin. ${ }^{74}$

- Administration of anti-inflammatory cytokines.

- More regular follow up.

Table 4 Novel intervention possibilities

\begin{tabular}{ll}
\hline Chronic heart failure & Malaria \\
\hline $\begin{array}{l}\text { Value of anti-TNF drugs not } \\
\text { proven in clinical trials }\end{array}$ & $\begin{array}{l}\text { Anti-TNF drugs may be useful in } \\
\text { malaria }\end{array}$ \\
$\begin{array}{l}\text { Intravenous immunoglobulin } \\
\text { may modulate peripartum } \\
\text { cardiomyopathy }\end{array}$ & $\begin{array}{l}\text { Intravenous immunoglobulin } \\
\text { useful in severe malaria }\end{array}$ \\
$\begin{array}{l}\text { Statins modulate CHF without } \\
\text { cachexia }\end{array}$ & $\begin{array}{l}\text { Statins may modulate malaria } \\
\text { without cachexia }\end{array}$ \\
$\begin{array}{l}\text { ACE inhibitors useful in all } \\
\text { stages of CHF }\end{array}$ & $\begin{array}{l}\text { ACE inhibitors maybe useful in } \\
\text { moderate to severe cachexia of } \\
\text { malaria, although the evidence }\end{array}$ \\
is not clear cut
\end{tabular}

\section{SIMILARITIES AND POTENTIAL FOR NOVEL INTERVENTION}

Table 4 lists the various points in the pathophysiology of these two diseases where it is theoretically possible for new intervention strategies to be applied.

\section{Modification of lipid profile}

Cytokines and endotoxin are known to stimulate triglycerides and cholesterol synthesis. ${ }^{75}$ Dyslipidaemia is a feature of severe malaria. ${ }^{76}$ Recent studies suggest that the inhibition of the enzyme 3-hydroxy-3-methylglutaryl coenzyme A (HMG CoA) reductase can interfere with the activation of antiinflammatory pathways in the body causing down-regulation of cytokine and chemokine production. This enzyme is raised in CHF and in malaria. ${ }^{77}$ Thus, there arises the question of whether the low blood levels of cholesterol seen in severe cachexia complicating chronic malaria should be viewed as an adverse prognostic marker and subject to the same therapeutic considerations as blood cholesterol levels in $\mathrm{CHF}^{78}{ }^{79}$ In CHF high and moderately raised levels of blood cholesterol would be treated with statins. Perhaps, the enhancement of the immunomodulatory effects of statins may see a novel role for HMG CoA reductase inhibitors in malaria. In contrast, cholesterol-rich serum lipoproteins are able to modulate the inflammatory immune response because they bind to, and detoxify, bacterial lipopolysaccharide whose production is increased in CHF and many chronic diseases. ${ }^{80}$

\section{Anticytokine drugs}

There are many probable therapeutic interventions that may modify the profiles of cytokines in chronic disease states. ${ }^{81} \mathrm{~A}$ summary is given below:

(1) Anti-inflammatory cytokines such as IL-10, IL-12, IL-18, and interferon suppress the inflammation and may play a part in therapeutic interventions.

(2) The inhibition of cytokine synthesis using drugs such as glucocorticoids, cyclosporine $\mathrm{A}, \mathrm{Th}_{2}$ selective inhibitors, myophenolate, and tacrolimus may modify cachexia.

(3) The administration of soluble cytokine receptors to mop up secreted cytokines.

(4) The use of humanised blocking antibodies to cytokines or their receptors.

(5) The use of drugs that block the signal transduction pathways activated by cytokines. ${ }^{82}$

Serum levels of uric acid are high and correlate with systemic inflammation in severe malaria and CHF. Anticytokine therapy using agents like pentoxifylline may be another ground common to both diseases. Two large clinical trials using etanercept, a TNF receptor analogue that blocks the effect of TNF, the RENAISSANCE and RECOVER, were stopped early in 2001 because they failed to demonstrate a benefit in patients with CHF. However, the addition of pentoxifylline to standard antimalarial treatment is known to decrease the duration of coma and mortality in patients with $P$ falciparum cerebral malaria as shown by Di Perri et al. ${ }^{83}$ This better outcome was associated with a decrease in serum TNF levels. Addition of pentoxifylline to treatment with standard heart failure drugs in patients with dilated cardiomyopathy may be associated with a significant improvement in left ventricular ejection fraction and symptoms. ${ }^{84}$

\section{Intravenous immunoglobins}

Recent evidence suggests that there may be a survival advantage in using intravenous immunoglobins in peripatum cardiomyopathy, CHF, and malaria..$^{85-87}$ The approach may be 
similar to the strategy in other chronic diseases like Kawasaki disease, dermatomyositis, and multiple sclerosis.

\section{CONCLUSION}

Many advances were made in our understanding of the pathogenesis of severe malaria and its sequelae in the second half of the last century. During the same period, notable advances were made in the management of CHF. Despite this, morbidity and mortality related to both diseases remain unacceptably high. The prognosis of patients with CHF remains poor, and malaria is re-emerging in areas once thought of as free from the disease. This may be because treatment in malaria is directed at the causative parasite and prevention of reinfection, while in CHF the empirical treatment of heart failure and lifestyle modification is the cornerstone of modern treatment. Our review of the literature suggests that there are significant similarities in the cachexia seen in CHF and that of malaria, especially as related to the effects of muscle mass and immunology. This challenges our understanding of recent techniques in modification of neurohormonal, cytokine, and lipid profiles and augmentation of lean muscle mass in CHF, and may present opportunities for novel therapeutic interventions.

\section{ACKNOWLEDGEMENTS}

Dr M E Onwuamaegbu received an honorarium of $£ 600$ from MSD in the last 12 months for giving lectures to general practitioners on cardiovascular infections.

We thank S D Anker and R A M Belcher for reviewing the paper and for their comments.

\section{Authors' affiliations}

M E Onwuamaegbu, M Henein, Department of Clinical Cardiology, Royal Brompton Hospital, London, UK

A J Coats, Dean's Office, Faculty of Medicine, University of Sydney, Sydney, New South Wales, Australia

\section{REFERENCES}

1 Hoffman SL, Subramanian GM, Collins FH, et al. Plasmodium, human and anopheles genomics and malaria. Nature 2002;415:702-9.

2 Clark IA, Cowden WB. The pathophysiology of falciparum malaria. Pharmacol Ther 2003;99:221-60.

3 Croft A. Malaria affects children and pregnant women most. BMJ 2000;321:1288.

4 World Health Organisation. Severe falciparum malaria. Trans $R$ Soc Trop Med Hyg 2000;94(suppl 1).

5 World Health Organisation. The world health report 1997. Conquering suffering, enriching humanity. Geneva: WHO Office of Information, 1997.

6 Kain KC, Keystone JS. Malaria in travellers. Epidemiology, disease and prevention. Infect Dis Clin North Am 1998;12:267-84.

7 Golgi C. Sull' infezione malarica. Arch Sci Med (Torino) 1886;10:109-35.

8 Maegraith B. Pathological processes in malaria and blackwater fever. Oxford: Blackwell, 1948

9 Kwiatkowski D, Hill AV, Sambou I, et al. TNF concentration in fatal cerebral, non-fatal cerebral, and uncomplicated Plasmodium falciparum malaria. Lancet 1990;336:1201-4.

10 Kern P, Hemmer CJ, Van-Damme J, et al. Elevated tumour necrosis factor alpha and interleukin- 6 serum levels as markers for complicated Plasmodium falciparum malaria. Am J Med 1989;87:139-43

11 Clark IA, Rockett KA. Nitric oxide and parasitic disease. Adv Parasitol 1996;37:1-56.

12 Urban BC, Ferguson DJP, Pain A, et al. Plasmodium falciparum-infected erythrocytes modulate the maturation of dendritic cells. Nature 1999;400:73-7.

13 Tachado SD, Gerold P, Schwarz R, et al. Signal transduction in macrophages by glycosyl-phosphatidylinositols of plasmodium, trypanosoma and leishmania: activation of protein tyrosine kinases and protein kinase $\mathrm{C}$ by inositolglycan and diacylglycerol moieties. Proc Natl Acad Sci USA 1997;94:4022-7.

14 Schofield L, Hackett F. Signal transduction in host cells by glycophosphatidylinositol toxin of malaria parasites. J Exp Med 1993;177:145-53.

15 Usawattanakul W, Tharavanii S, Warrell DA, et al. Factors contributing to the development of cerebral malaria II. Endotoxin Clin Exp Immunol 1985:61:562-8.

16 Clark IA, Awburn MM, Whitten RO, et al. Tissue distribution of migration inhibitory factor and inducible nitric oxide synthase in falciparum malaria and sepsis in African children. Malaria Journal 2003;2:6.
17 Carswell F, Hughes AO, Palmer RI, et al. Nutritional status, globulin titers, and parasitic infections of two populations of Tanzanian school children. Am J Clin Nutr 1981;34:1292-9.

18 Staalsoe T, Shulman CE, Bulmer JN, et al. Variant surface-specific lgG and protection against clinical consequences of pregnancy-associated Plasmodium falciparum malaria. Lancet 2004;363:283-9.

19 Dominguez-Vazquez A, Alzate-Sanchez A. Estado nutricional en ninos menores de seis anos y su asociacion con malaria y parasitismo intestinal. [Nutritional status in children aged less than nine years, and its association with malaria and intestinal parasites.] Salud Publica Mex 1990;32:52-63.

20 Hendrickse RG, Hasan AH, Olumide LO, et al. Malaria in early childhood. An investigation of five hundred seriously ill children in whom a "clinical" diagnosis of malaria was made on admission to the children's emergency room at University College Hospital, Ibadan. Ann Trop Med Parasitol 1971;65: 1-20.

21 Deen JL, Walraven GE, von Seidlein L. Increased risk for malaria in chronically malnourished children under 5 years of age in rural Gambia. J Trop Pediatr 2002;48:78-83.

22 Genton B, Al Yaman F, Ginny M, et al. Relation of anthropometry to malaria morbidity and immunity in Papua New Guinean children. Am J Clin Nutr 1998;68:734-41

23 Tanner M, Burnier E, Mayombana C, et al. Longitudinal study on the health of children in a rural Tanzanian community: parasitoses and nutrition following control measures against intestinal parasites. Acta Trop 1987;44:137-74.

24 Mbago MC, Namfua PP. Some determinants of nutritional status of one to four-year old children in low income urban areas in Tanzania. J Trop Pediatr 1991;38:299-306.

25 Van Den Broeck J, Eeckels R, Vuylsteke J. Influence of nutritional status on child mortality in rural Zaire. Lancet 1993;341:1491-5.

26 Cleland JG. Controversies in the management of heart failure. Edinburgh: Churchill Livingstone, 1997, vii-viii (foreward).

27 Task Force for the Diagnosis and Treatment of Chronic Heart Failure, European Society of Cardiology. Remme WJ, Swedberg K, co-chairmen. Guidelines for the diagnosis and treatment of chronic heart failure. Eur Heart $J$ 2001;22:1527-60.

28 Otaki M. Surgical treatment of patients with cardiac cachexia. An analysis of factors affecting operative mortality. Chest 1994;105:1347-51.

29 Carr JG, Stevenson LW, Walden JA, et al. Prevalence and hemodynamic correlates of malnutrition in severe congestive heart failure secondary to ischemic or idiopathic dilated cardiomyopathy. Am J Cardiol 1989:63:709-13.

30 Anker SD, Coats AJS. Syndrome of cardiac cachexia. Poole-Wilson PA, Colucci WS, Massie BM, et al. Heart failure: scientific principles and clinical practice. Edinburgh: Churchill Livingstone, 1997;18:261-7.

31 Roubenoff R, Kehayias JJ. The meaning and measurement of lean body mass. Nutr Rev 1991;49:163-75.

32 Katz AM, Katz PB. Diseases of the heart in works of Hippocrates. Br Heart J 1962;24:257-64.

33 Aronson JK. An account of the foxglove and its medical uses. London: Oxford University Press, 1985:11-100.

34 Lipkin D, Jones D, Round J, et al. Abnormalities of skeletal muscle in patients with chronic heart failure. Int J Cardiol 1988;18:187-95.

35 Minotti JR, Pillay P, Oka R, et al. Skeletal muscle size. Relationship to muscle function in heart failure. J Appl Physiol 1993;75:373-81.

36 Coats AJS, Clark AL, Piepoli $M$, et al. Symptoms and quality of life in hear failure; the muscle hypothesis. Br Heart J 1994;72:S36-9.

37 Coats AJS. The "muscle hypothesis" of chronic heart failure. J Mol Cell Cardiol 1996;28:2255-62.

38 Nuhr MJ, Pette D, Berger R, et al. Beneficial effects of chronic low-frequency stimulation of thigh muscles in patients with advanced chronic heart failure. Eur Heart J 2004;25:136-43.

39 Merrill AJ, Morrison JR, Brannon ES. Concentration of renin in renal venous blood in patients with congestive heart failure. Am J Med 1946;1:468-73.

40 Davis JO. Mechanism of salt and water retention in congestive heart failure. The role of aldosterone. Am J Med 1960;19:486-90.

41 Laragh $\mathrm{JH}$. Hormones and the pathogenesis of congestive heart failure: vasopressin, aldosterone and angiotensin II. Circulation 1962;25:1015-18.

42 Kubo SH. The role of neurohormonal activation in the pathophysiology and prognosis of patients with congestive heart failure. Coron Artery Dis 1993;4:4-10.

43 Packer $M$. The neurohormonal hypothesis: a theory to explain the mechanism of disease progression in heart failure. J Am Coll Cardiol 1992;20:248-54.

44 Anker SD, Chua TP, Ponikowski P, et al. Hormonal changes and catabolic/ anabolic imbalance in chronic heart failure and their importance for cardiac cachexia. Circulation 1997;96:526-34.

45 Levine B, Kalman J, Mayer L, et al. Elevated circulating levels of tumor necrosis factor in severe chronic heart failure. N Engl J Med 1990;323:236-41.

46 Francis GS. Vasoactive hormone systems. Poole-Wilson PA, Colucci WS, Massie BM, et al, eds. Heart failure: scientific principles and clinical practice. Edinburgh: Churchill Livingstone, 1997;15:215-34.

47 James TN. Normal and abnormal consequences of apoptosis in the human heart. From postnatal morphogenesis to paroxysmal arrhythmias. Circulation 1994;90:556.

48 Swan JW, Walton C, Godsland IF, et al. Insulin resistance in chronic heart failure. Eur Heart J 1994;15:1528-32.

49 Davis TME, Pukrittayakamee S, Supanaranond W, et al. Glucose metabolism in quinine-treated patients with uncomplicated falciparum malaria. Clin Endocrinol (Oxf) 1990;33:739-49.

50 Gaillard R-C, Spinedi E, Chautard T, et al. Cytokines, leptin, and the hypothalamo-pituitary-adrenal axis. Ann N Y Acad Sci 2000:917647-57. 
51 Pekala PH, Price SR, Horn CA, et al. Model for cachexia in chronic disease: secretory products of endotoxin-stimulated macrophages induce a catabolic state in 3T3-L1 adipocytes. Trans Assoc Am Physicians 1984;97:251-9.

52 Doehner W, Pflaum CD, Rauchhaus $M$, et al. Leptin, insulin sensitivity and growth hormone binding protein in chronic heart failure with and without cardiac cachexia. Eur J Endocrinol 2001;145:727-35.

53 Morrison WL, Gibson JN, Rennie MJ. Skeletal muscle and whole body protein turnover in cardiac cachexia: influence of branched-chain amino acid administration. Eur J Clin Invest 1988;18:648-54.

54 Adigun AQ, Ajayi AA. The effects of enalapril-digoxin-diuretic combination therapy on nutritional and athropometric indices in chronic congestive heart failure: preliminary findings in cardiac cachexia. Eur J Heart Failure $2001 ; 3: 359-63$.

55 Karunaweera ND, Grau GE, Gamage R, et al. Dynamics of fever and serum levels of tumor necrosis are closely associated during clinical paroxysms in Plasmodium vivax malaria. Proc Natl Acad Sci USA 1992;89:3200-3.

56 Hotez PJ, Le Trang N, Fairlamb AH, et al. Lipoprotein lipase suppression in 3T3-L1 cells by a haematoprotozoan-induced mediator from peritoneal exudate cells. Parasite Immunol 1984;3:203-9.

57 Hirunpetcharat C, Finkelman F, Clark IA, et al. Malaria parasite-specific Th 1 like T cells simultaneously reduce parasitemia and promote disease. Parasite Immunol 1999;21:319-29.

58 Hensmann M, Kwiatkowski D. Cellular basis of early cytokine response to Plasmodium falciparum. Infect Immun 2001;69:2364-71.

59 Akanmori BD, Kurtzhals JAL, Goka BQ, et al. Distinct patterns of cytokine regulation in discrete clinical forms of Plasmodium falciparum malaria. Eur Cytokine Netw 2000;11:113-18.

60 Othoro C, Laa AA, Nahlen B, et al. A low interleukin-10 tumour necrosis factor- $\alpha$ ratio is associated with malaria anaemia in children residing in holoendemic malaria region in Western Kenya. J Infect Dis 1999;179:279-82.

61 Allan RJ, Beattie P, Bate C, et al. Strain variation in tumor necrosis factor induction by parasites from children with acute falciparum malaria. Infect Immun 1995:63:1173-5.

62 Singh S, Singh N, Handa R. Tumor necrosis factor-alpha in patients with malaria. Indian J Malariol 2000;37:27-33.

63 Migot-Nabias F, Deloron P, Ringwald P, et al. Immune response to Plasmodium falciparum liver stage antigen-1: geographical variations within Central Africa and their relationship with protection from clinical malaria. Trans R Soc Trop Med Hyg 2000;94:557-62.

64 Nussenblatt V, Mukasa G, Metzger A, et al. Anaemia and interleukin-10, tumor necrosis factor alpha, and erythropoietin levels among children with acute uncomplicated Plasmodium falciparum malaria. Clin Diagn Lab Immunol 2001;8:1164-70.

65 Jason J, Archibald LK, Nwanyanwu OC, et al. Comparison of serum and cell-specific cytokines in humans. Clin Diagn Lab Immunol 2001;8:1097-103.

66 Ferrari R. The role of TNF in cardiovascular disease. Pharmacol Res 1999;40:97-105

67 Krown KA, Page MT, Nguyen C, et al. Tumor necrosis factor alpha-induced apoptosis in cardiac myocytes. J Clin Invest 1996;98:2854-65.

68 Kurtzhals JAL, Adabayeri V, Goka BQ, et al. Low plasma concentrations of interleukin 10 in severe malarial anaemia compared with cerebral and uncomplicated malaria. Lancet 1998;351:1768-72.
69 Cicoira M, Bolger AP, Doehner W, et al. High tumour necrosis factor-alpho levels are associated with exercise intolerance and neurohormonal activation in chronic heart failure patients. Cytokine $2001 ; 15: 80-6$.

70 Wattavidanage J, Carter R, Perera KL, et al. TNF- $\alpha 2$ marks high risk of severe disease during Plasmodium falciparum malaria and other infections in Sri Lankans. Clin Exp Immunol 1999; 1 15:350-5.

71 Modiano D, Petrarca V, Sirima BS, et al. Different response to Plasmodium falciparum malaria in west African sympatric ethnic groups. Proc Natl Acac Sci USA 1996;93:13206-11

72 Anker SD, Negassa A, Coats AJS, et al. Prognostic importance of weight loss in chronic heart failure and the effect of treatment with angiotensin-convertingenzyme inhibitors: an observational study. Lancet 2003;361:1077-83.

73 Coats AJS, Adamopoulos S, Meyer TE, et al. Effects of physical training in chronic heart failure. Lancet 1990;335:63-6.

74 Mc Namara DM, Holubkov R, Starling RC, et al. Controlled trial of intravenous immune globulin in recent-onset dilated cardiomyopathy. Circulation $2001 ; 103: 2254-9$

75 Feingold KR, Serio MJ, Adi S, et al. Tumor necrosis factor stimulates hepatic lipid synthesis and secretion. Endocrinology 1989:24:2336-42.

76 Mohanty S, Mishra SK, Das BS, et al. Altered plasma lipid pattern in falciparum malaria. Ann Trop Med Parasitol 1992;86:601-6.

77 Drexler H, Hornig BD. Endothelial dysfunction in human disease. J Mol Cell Cardiol 1999;31:51-60.

78 Sein KK, Aikawa M. The prime role of plasma membrane cholesterol in the pathogenesis of immune evasion and clinical manifestations of falciparum malaria. Med Hypotheses 1998;51:105-10.

79 Kiekshus J. Debate: statins should be used in patients with heart failure. Curr Control Trials Cardiovasc Med $2001 ; 2: 268-70$.

80 Rauchhaus $M$, Koloczek V, Volk HD, et al. Inflammatory cytokines and possible immunological role for lipoproteins in chronic heart failure. Int J Cardiol 2000;76:125-33.

81 Barnes PJ. Therapeutic strategies for allergic diseases. Nature 2000:402:B31-8.

82 Barnes PJ. Cytokine modulators as novel therapies for asthma. Annu Rev Pharmacol Toxicol 2002;42:81-98.

83 Di Perri G, Di Perri IG, Monteiro GB, et al. Pentoxifylline as a supportive agent in the treatment of cerebral malaria in children. J Infect Dis 1995:171:1317-22.

84 Skudicky D, Bergmann A, Silwa K, et al. Beneficial effects of pentoxifylline in patients with idiopathic dilated cardiomyopathy treated with angiotensinconverting enzyme inhibitors and carvedilol. Circulation 2001;103:1083-8.

85 Bozkurt B, Villaneuva FS, Holubkov R, et al. Intravenous immune globulin in the therapy of peripartum cardiomyopathy. J Am Coll Cardiol 1999;34:177-80.

86 Sabchareon A, Burnouf T, Ouattara D, et al. Parasitologic and clinical response to immunoglobulin administration in falciparum malaria. Am J Trop Med Hyg 1991;45:297-308.

87 Gullestad L, Aass H, Field JG, et al. Immunomodulating therapy with intravenous immunoglobin in patients with chronic heart failure. Circulation $2001 ; 103: 220-5$

88 Kikafunda JK, Walker AF, Collett D, et al. Risk factors for early childhood malnutrition in Uganda. Pediatrics 1998;102:e45.

89 Nacher M, Singhasivanon P, Vannaphan S, et al. Socio-economic and environmental protective/risk factors in severe malaria in Thailand. Acta Trop 2001;78:139-46.

\section{CORRECTION}

doi: 10.1136/pgmj.2004.019356corrl

An error occurred in the paper "Chorea and related disorders" by Bhidayasiri and Truong published in the September issue (Postgrad Med J 2004;80:527-34). On page 528, “Box 1: Clinical features of Huntington's disease", the 8th bullet point should read "No curative treatment; symptomatic treatment with dopamine antagonists". 